like the purple variety. Microscopic examination showed that what appeared to be lateral nerves were not due to bundles, but were merely folds. Nevertheless they afford a striking character difference between the two forms.

The bushes under consideration are identified as Syringa persica with some doubt. The upper surface of the leaves lacks stomata, which should be present in $S$. persica, as defined by ScHNEIDER in his Handbuch der Laubholzkunde. The flowers are sterile, a fact which would presumably point to a hybrid ancestry, and the terminal bud is not suppressed, but generally gives rise to a panicle. The flowers are produced, then, from lateral and terminal buds on the wood of the preceding year. The bushes were purchased as $S$. persica, which seems, on the whole, the most applicable name.

The color of the wild lilacs is purple. A light-colored variety, such as the one which produced this bud sport, might be judged, a priori, to be a Mendelian recessive. If it should be found to be so, the reversion to the original purple would be distinctly interesting, from the standpoint of the now almost discarded presence and absence hypothesis. If not a reversion, it might be either a case of what has been called somatic segregation, or a periclinal chimaera. These hypotheses will be tested, if possible; but since the evidence, if obtainable at all, must be long delayed, it is thought worth while to report the mere fact that such a bud sport has been observed.-FRIEDA COBB AND H. H. BARTLETT, University of Michigan, Ann Arbor, Mich.

\title{
METHOD FOR STAINING ANTHEROZOID OF FERN
}

\section{(WITH ONE FIGURE)}

Some time ago the writer had a favorable opportunity to study spermatogenesis in some of the common ferns, and it was found desirable to perfect a staining technique by means of which it was possible to stain the cilia and at the same time to differentiate clearly the different parts of the body of the antherozoid. Of the various methods employed the following proved most satisfactory: (I) kill antherozoids in a drop of water on a slide by inverting the slide over a vial containing a $\mathrm{I}$ per cent osmic acid solution (the drop of water should be small and when placed on the slide spread out so as to form a thin film); (2) dry slide in air; (3) stain in safranin ro minutes to I hour; (4) wash in water; (5) wash in 95 per cent alcohol until only the nucleus remains stained; if necessary, 
use xylol to clear and then remove the xylol with 95 per cent and absolute alcohol; (6) stain in acid fuchsin 10-20 seconds; (7) wash in absolute alcohol; (8) clear in clove oil and xylol; (9) seal in balsam.

The nucleus is stained a bright red by the safranin, while the cytoplasmic portions of the antherozoid are stained a bluish pink. The blepharoplast is more densely stained than the cytoplasmic envelope.

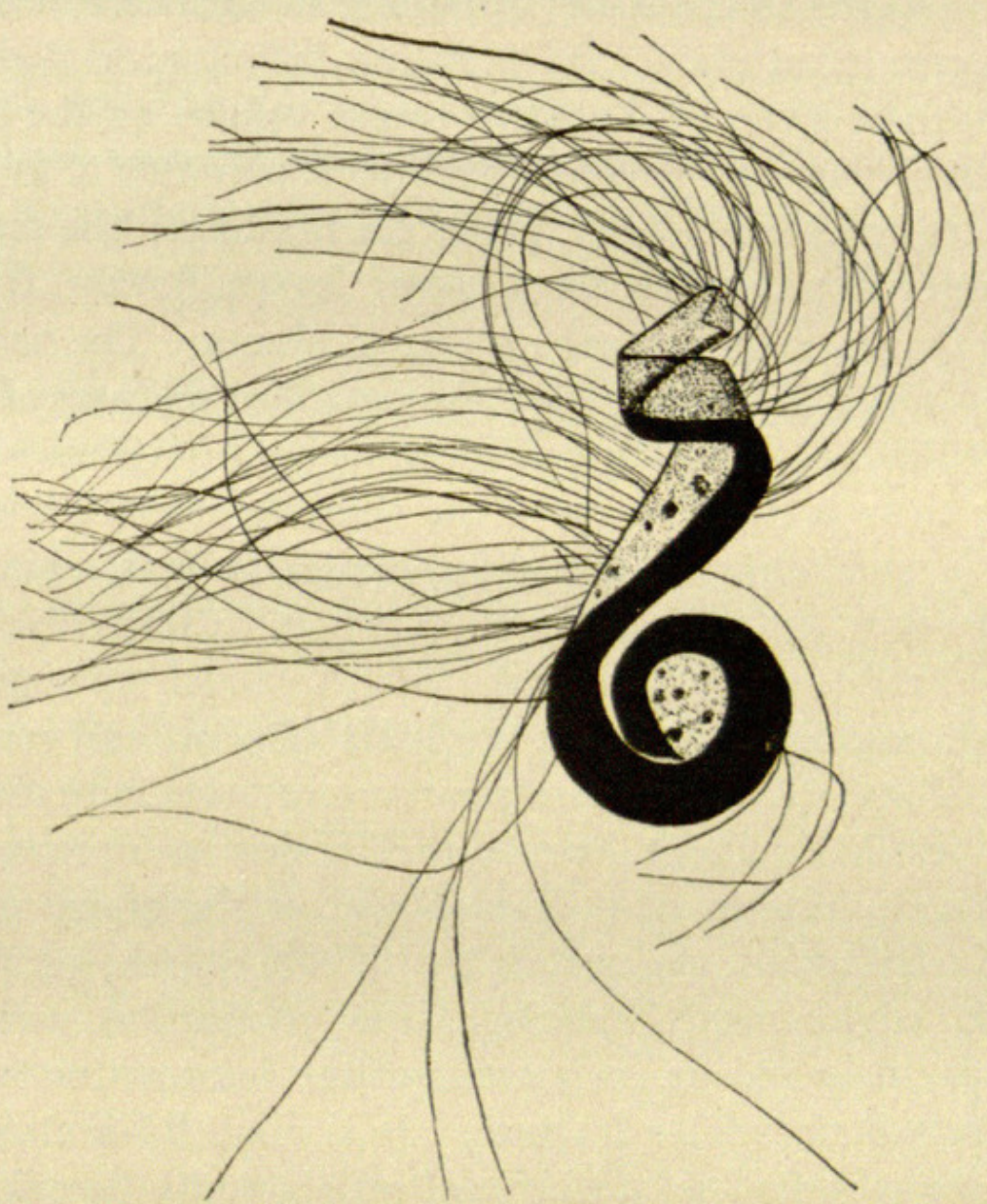

FIG. I.-Antherozoid of Onoclea struthiopteris; $\times 3700$ and reduced one-half in reproduction.

The cilia of the antherozoid are attached for some length along the blepharoplast, as shown in fig. I. No cilia are attached to the extreme anterior portion of the blepharoplast. The envelope at the anterior end extends a short distance beyond the nucleus, which is small and rodlike at this extremity. The nature of the denser portions in the envelope is not understood. These were of constant occurrence when the method described was used. They could also be readily observed in the living antherozoid. Some very good results were obtained when iron haematoxylin was substituted for the safranin.-W. N. STEIL, University of Wisconsin, Madison, Wis. 


\section{$2 \mathrm{BHL}$ Biodiversity Heritage Library}

Steil, W N. 1918. "Method for Staining Antherozoid of Fern." Botanical gazette 65(6), 562-563. https://doi.org/10.1086/332291.

View This Item Online: https://www.biodiversitylibrary.org/item/109339

DOI: https://doi.org/10.1086/332291

Permalink: https://www.biodiversitylibrary.org/partpdf/224029

\section{Holding Institution}

Missouri Botanical Garden, Peter H. Raven Library

\section{Sponsored by}

Missouri Botanical Garden

\section{Copyright \& Reuse}

Copyright Status: Public domain. The BHL considers that this work is no longer under copyright protection.

This document was created from content at the Biodiversity Heritage Library, the world's largest open access digital library for biodiversity literature and archives. Visit BHL at https://www.biodiversitylibrary.org. 